University of Nebraska - Lincoln

DigitalCommons@University of Nebraska - Lincoln

\title{
Effects of Sediment Load on Emergence of Aquatic Invertebrates and Plants from Wetland Soil Egg and Seed Banks
}

Robert A. Gleason

U.S. Geological Survey, rgleason@usgs.gov

Ned H. Euliss Jr.

U.S. Geological Survey, ceuliss@usgs.gov

Daniel E. Hubbard

South Dakota State University

Walter G. Duffy

Humboldt State University

Follow this and additional works at: https://digitalcommons.unl.edu/usgsnpwrc

Gleason, Robert A.; Euliss, Ned H. Jr.; Hubbard, Daniel E.; and Duffy, Walter G., "Effects of Sediment Load on Emergence of Aquatic Invertebrates and Plants from Wetland Soil Egg and Seed Banks" (2003). USGS Northern Prairie Wildlife Research Center. 268.

https://digitalcommons.unl.edu/usgsnpwrc/268

This Article is brought to you for free and open access by the US Geological Survey at DigitalCommons@University of Nebraska - Lincoln. It has been accepted for inclusion in USGS Northern Prairie Wildlife Research Center by an authorized administrator of DigitalCommons@University of Nebraska - Lincoln. 


\title{
EFFECTS OF SEDIMENT LOAD ON EMERGENCE OF AQUATIC INVERTEBRATES AND PLANTS FROM WETLAND SOIL EGG AND SEED BANKS
}

\author{
Robert A. Gleason ${ }^{1}$, Ned H. Euliss, Jr. ${ }^{1}$, Daniel E. Hubbard ${ }^{2}$, and Walter G. Duffy ${ }^{3}$ \\ ${ }^{1}$ U.S. Geological Survey \\ Northern Prairie Wildlife Research Center \\ 8711 37th Street Southeast \\ Jamestown, North Dakota, USA 58401-7317 \\ ${ }^{2}$ South Dakota State University \\ Department of Wildlife and Fisheries Sciences \\ Brookings, South Dakota, USA 57007 \\ ${ }^{3}$ California Cooperative Fish and Wildlife Research Unit \\ U.S. Geological Survey \\ Humboldt State University \\ Arcata, California, USA 95521
}

\begin{abstract}
Intensive agricultural activities near prairie wetlands may result in excessive sediment loads, which may bury seed and invertebrate egg banks that are important for maintenance and cycling of biotic communities during wet/dry cycles. We evaluated effects of sediment burial on emergence of plants and invertebrates from seed and invertebrate egg banks. Sediment-load experiments indicated that burial depths of $0.5 \mathrm{~cm}$ caused a $91.7 \%$ reduction in total seedling emergence and a $99.7 \%$ reduction in total invertebrate emergence. Results of our burial experiments corroborated prior research on seedling emergence. However, our study demonstrated that invertebrate emergence is also highly susceptible to the effects of burial. Our research suggests that sediment entering wetlands from agricultural erosion may also hamper successional changes throughout interannual climate cycles. Land-management strategies need to be implemented that will prevent erosion of cropland top soil from entering wetlands.
\end{abstract}

Key Words: agricultural impacts, egg banks, hydrophytes, prairie potholes, resting eggs, sedimentation, seed banks, siltation, tillage, wetland condition, wetland degradation

\section{INTRODUCTION}

Aquatic invertebrate egg and plant seed banks are critical to reestablishment of vegetative and invertebrate communities of wetlands as they alternate between wet and dry phases in the prairie pothole region (PPR) (van der Valk and Davis 1978, van der Valk 1981, Euliss et al. 1999). The PPR undergoes extreme interannual climatic variation, which results in great fluctuations in water levels, hydroperiods, and salt concentrations of wetlands (Euliss et al. 1999). Plants and invertebrates that repopulate wetland basins following dry conditions often are recruited from invertebrate egg and plant seed banks present in wetland sediments. Frequently, relic propagules in drained wetlands facilitate initial recolonization of plant and invertebrate communities in recently restored wetlands (Galatowitsch and van der Valk 1994). However, agricultural practices often degrade wetland invertebrate egg and seed banks. For example, prolonged drainage, cultivation, crushing (e.g., from farm equipment), and/ or artificially shortened hydroperiods may reduce or eliminate invertebrate egg and plant seed banks (Wienhold and van der Valk 1989, Galatowitsch and van der Valk 1994, 1996, Hathaway et al. 1996, Euliss and Mushet 1999).

Another disturbance that has great potential to impact invertebrate and plant soil propagules in wetlands is erosion and translocation of upland soil into wetland basins. Sedimentation rates in agricultural wetlands often are orders of magnitude higher than in natural grassland landscapes (Adomaitis et al. 1967, Martin and Hartman 1987, Dieter 1991, Luo et al. 1997, 1999, Gleason and Euliss 1998, Gleason 1996, 2001). Eroded soils from agricultural fields may cover viable seed and egg banks, thus limiting recruitment in reflooded wetlands (Euliss and Mushet 1999). In vitro experiments have shown that sediment burial depths of as little as $2.5 \mathrm{~mm}$ can reduce species richness, emergence, and germination of hydrophytes (Jurik et al. 


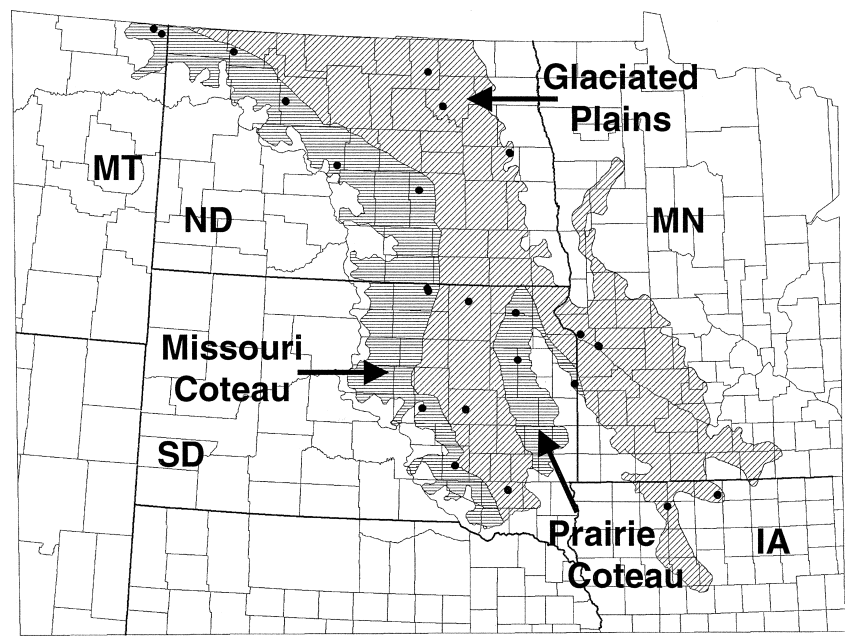

Figure 1. General location of wetlands sampled $(n=46)$ during 1997 in the United States Prairie Pothole Region. In most cases, because of overlap, a single dot represents the location of two wetlands (i.e., seasonal and semipermanent).

1994, Wang et al. 1994); similar studies have not been conducted on invertebrate egg banks of prairie wetlands. However, Kasahara et al. (1975) and Uye et al. (1979) demonstrated that eggs of marine copepods did not hatch when buried beneath sediments, but these studies did not report the burial depths tested. The goal of our study was to assess effects of sediment burial on emergence of invertebrates from egg banks. Additionally, we examined effects of sediment burial on emergence of plants from seed banks to compare sediment responses of plants and invertebrates.

\section{METHODS AND MATERIALS}

\section{Field Methods}

During June to September 1997, we collected soil samples (i.e., invertebrate egg and plant seed bank samples) from 46 wetlands in the PPR that included portions of Montana, North Dakota, South Dakota, Minnesota, and Iowa (Figure 1). These sites were used as reference wetlands within a larger overall study to evaluate recovery of seed and invertebrate egg banks in restored wetlands in the PPR (Gleason 2001). We used a systematic sampling design stratified by three physiographic regions (Missouri Coteau, Prairie Coteau, and Glaciated Plains; map based on Kantrud 1993 and Bluemle 1977) to select a representative sample of wetlands in the PPR of the United States. Using a geo-referenced map of the PPR depicting the three major physiographic regions (Figure 1), we drew a line along the medial portions of each physiographic region that follows the long natural orientation (i.e., north-south) of these regions. Along each axis line, we systematically identified nine sampling points in the
Missouri Coteau, three in the Prairie Coteau, and twelve in the Glaciated Plains (Figure 1); allocation of sampling points was proportional to the linear length of each physiographic region. Near each sampling point, we selected one seasonal and one semipermanent wetland (Class III and IV wetlands; Stewart and Kantrud 1971) with no history of cultivation in the wetland basin or catchment (i.e., reference wetlands); however, some of the wetland basins $(23 \%)$ were grazed. The sampling effort resulted in the selection of 46 wetlands. Ideally, our sampling effort would have resulted in the selection of 48 wetlands ( 24 sampling points $\times 2$ wetland classes $=48$ ), but certain wetland categories were not readily available near each sampling point.

Of the 46 wetlands selected for study, 24 were seasonal and 22 semipermanent. We collected soil samples from four randomly established transects that radiated from the center of each wetland to the outer edge of the wet-meadow zone (zone classification follows Stewart and Kantrud 1971). From each transect, we collected three cores to a depth of $5 \mathrm{~cm}$ in the wetmeadow and shallow-marsh zone using a 7.5 -cm-diameter corer. Seed-bank samples were stored at $4^{\circ} \mathrm{C}$, and invertebrate egg-bank samples were stored frozen at $<0^{\circ} \mathrm{C}$ until needed for laboratory experiments (Table 1).

\section{Laboratory Methods}

Of the 46 wetlands sampled, we randomly selected 37 (17 seasonal and 20 semipermanent) for invertebrate egg-bank experiments and 36 (19 seasonal and 17 semipermanent) for seed-bank experiments because of limitations in greenhouse space and number of aquaria. In the laboratory, we composited the soil samples from each wetland (combined soil samples from wet-meadow and shallow-marsh zones) and mixed and sieved the soils to remove litter, roots, and tubers. We created burial treatments for invertebrate incubation experiments by placing a subsample $\left(380 \mathrm{~cm}^{3}\right)$ of wetland soil from each wetland composite sample into each of four flats $(19.5 \times 19.5 \times 6 \mathrm{~cm})$. This resulted in a soil depth of ca. $1 \mathrm{~cm}$. Soils in flats were then overlain with $0,0.5,1$, and $2 \mathrm{~cm}$ of steam-sterilized upland soil. We prepared flats for seed-bank experiments using similar procedures; however, wetland soils were underlain with $3,2.5,2$, and $1 \mathrm{~cm}$ of steamsterilized sand for the 0-, 0.5-, 1-, and $2-\mathrm{cm}$ burial treatments, respectively. Additional flats containing only upland soils also were prepared and subjected to experimental conditions to verify that they were free of viable eggs or seeds (33 and 28 control flats for egg- and seed-bank experiments, respectively) (see Table 1). No invertebrates or seedlings emerged from 
Table 1. Start dates for invertebrate egg-bank and plant seed-bank experimental trials by wetland class and physiographic region.

\begin{tabular}{|c|c|c|c|c|c|}
\hline $\begin{array}{c}\text { Experiment } \\
\text { Type }\end{array}$ & $\begin{array}{l}\text { Wetland } \\
\text { Class }\end{array}$ & $\begin{array}{c}\text { Physiographic } \\
\text { Region }\end{array}$ & $\begin{array}{l}\text { Number of } \\
\text { Wetlands }\end{array}$ & $\begin{array}{l}\text { Number of }{ }^{\mathrm{b}} \\
\text { Control Flats }\end{array}$ & $\begin{array}{l}\text { Experiment } \\
\text { Start Date }\end{array}$ \\
\hline \multirow[t]{4}{*}{ Egg bank } & \multirow[t]{2}{*}{ Seasonal } & Glaciated Plains & 9 & 5 & 31 Jan 1998 \\
\hline & & Missouri and Prairie Coteau & 8 & 8 & 4 Apr 1998 \\
\hline & \multirow[t]{2}{*}{ Semipermanent } & Glaciated Plains & 10 & 10 & 10 Jun 1998 \\
\hline & & Missouri and Prairie Coteau & 10 & 10 & 5 Aug 1998 \\
\hline \multirow[t]{2}{*}{ Seed bank } & Seasonal & All & 12 & 1 & 8 Feb 1998 \\
\hline & Semipermanent & All & 12 & 1 & 9 May 1998 \\
\hline
\end{tabular}

a Number of wetlands used during each experimental run (i.e., wetland class-physiographic region combination).

${ }^{\mathrm{b}}$ Number of control flats containing only upland soils used to overlay wetland soils.

these control flats. Upland soil used to overlay wetland soils had a silty-clay-loam texture and was sieved through $0.017-\mathrm{mm}$ mesh to concentrate particle sizes similar to erosional sediment (Martin and Hartman 1987). Upland soil was provided by U.S. Department of Agriculture's Northern Grain Insects Research Laboratory, Brookings, South Dakota and was determined to be free of agrochemical residues.

We performed invertebrate incubation experiments in an environmentally controlled room at the U.S. Geological Survey's Northern Prairie Wildlife Research Center, Jamestown, North Dakota. Egg bank burial experiments were conducted in conjunction with other egg-bank studies (Gleason 2001) that required experiments to be stratified by wetland class and physiographic region. We performed experimental trials in the following order: (1) Glaciated Plains seasonal wetlands, (2) Missouri and Prairie Coteau seasonal wetlands, (3) Glaciated Plains semipermanent wetlands, and (4) Missouri and Prairie Coteau semipermanent wetlands. Number of wetlands used for burial experiments during each experimental trial and experimental trial-initiation dates are summarized in Table 1. Procedures used for incubating invertebrates from soil egg-bank samples, including maintenance of photoperiod, water chemistry, and temperature regimes, were similar to those described by Euliss and Mushet (1999). We randomly assigned experimental flats to aquaria $(37.8 \mathrm{~L})$ containing well water adjusted (i.e., by adding distilled water) to a specific conductance within the range typical of seasonal $\left(700 \mu \mathrm{S} \mathrm{cm}{ }^{-1}\right)$ or semipermanent (1400 $\mu \mathrm{S} \mathrm{cm}^{-1}$ ) wetlands (Stewart and Kantrud 1971). Soil samples were incubated in aquaria for six weeks; temperatures were maintained at $10^{\circ} \mathrm{C}$ for the first three weeks and then raised to $20^{\circ} \mathrm{C}$ for the remainder of the experiment. Photoperiod was maintained at $12 \mathrm{~h}$ light: $12 \mathrm{~h}$ dark, and aquaria were aerated. We checked aquaria temperatures daily and added distilled water to maintain water levels and salt concentrations. During the six-week incubation, we harvested invertebrates from aquaria every two weeks by siphoning the water from the aquaria through a 0.1 - $\mathrm{mm}$ screen to concentrate invertebrates. The siphoned water was then returned to the aquaria. All harvested invertebrates were enumerated and identified following Pennak (1989).

We conducted seedling emergence experiments in an environmentally controlled greenhouse at the U.S. Department of Agriculture's Northern Grain Insects Research Laboratory, Brookings, South Dakota. Seedbank burial experiments were conducted in conjunction with other seed bank studies (Gleason 2001) that required separate experimental trials for each wetland class. Initiation dates for seasonal and semipermanent wetland seed bank experiments are summarized in Table 1. Flats were placed on a greenhouse bench in a randomized complete block design with wetlands serving as blocks and the four sediment depths (i.e., 0, 0.5, 1 , and $2 \mathrm{~cm}$ ) being treatments. We maintained soils in a saturated state to simulate the drawdown phase of wetlands and to stimulate germination of mudflat annual and perennial emergents (van der Valk and Davis 1978). Greenhouse temperature and photoperiod were increased incrementally during the experiment to simulate environmental conditions from May to July (i.e., temperature range $15-30^{\circ} \mathrm{C}$; light range $14-16 \mathrm{hrs}$ ). Greenhouse temperatures ranged from 9 to $37^{\circ} \mathrm{C}$ during seasonal wetland experiments and 11 to $37^{\circ} \mathrm{C}$ during semipermanent wetland experiments. These environmental conditions provided a range of alternating temperatures and photoperiods that are critical factors in seed germination (Galinato and van der Valk 1986, Baskin and Baskin 1998, Hartleb et al. 1993). Seedlings were counted and removed as they reached an identifiable stage. After three months, all unknown seedlings were transferred to pots and grown to an identifiable stage. Plant species nomenclature follows Great Plains Flora Association (1986).

\section{Statistical Methods}

We used analysis of variance (ANOVA) to assess the effects of burial depth on numbers of seedlings and invertebrates that emerged. We conducted ANOVAs 


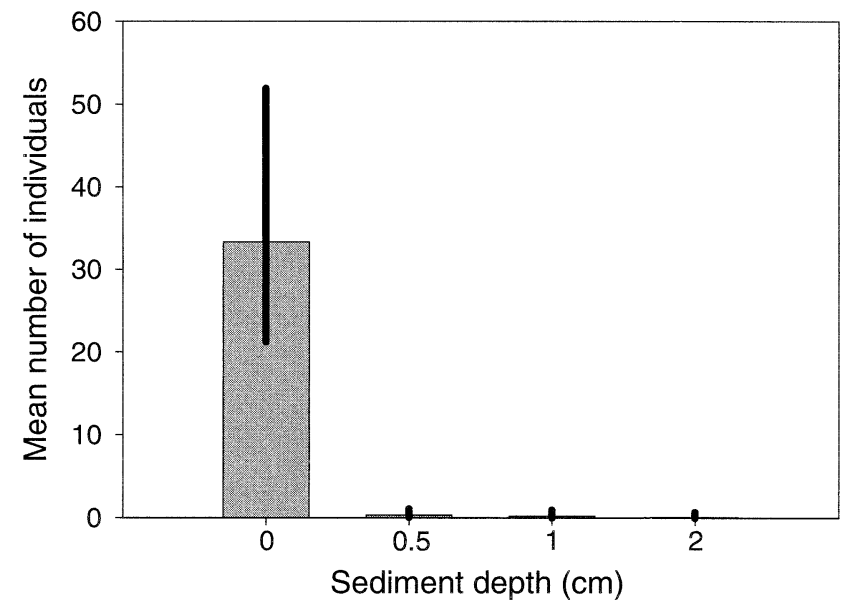

Figure 2. Back-transformed mean number of individuals and $95 \%$ confidence intervals of invertebrates incubated from soil egg banks in each sediment-burial treatment.

using the mixed model procedure (PROC MIXED) of SAS (SAS Institute, Inc. 1997) using a randomized block design; each wetland replicated across the four burial treatments represented a block. The ANOVA model included wetland, which was a random effect, and burial depth, which was a fixed effect. Prior to analysis, transformations $(\ln [$ count +1$])$ were performed on the data to stabilize variances (Steel and Torrie 1980). Fisher's protected least significant difference tests (LSD) were used to assess individual differences when main effects were significant $(P<0.05)$ (Milliken and Johnson 1984). Here, we report backtransformed means and confidence intervals.

\section{RESULTS}

Effects of Sediment Load on Aquatic Invertebrate Emergence

Ostracods, copepods, and three families of cladocerans (Daphnidae, Macrothricidae, and Chydoridae) were the only invertebrate taxa successfully incubated during aquarium experiments. Our lowest level sedi-

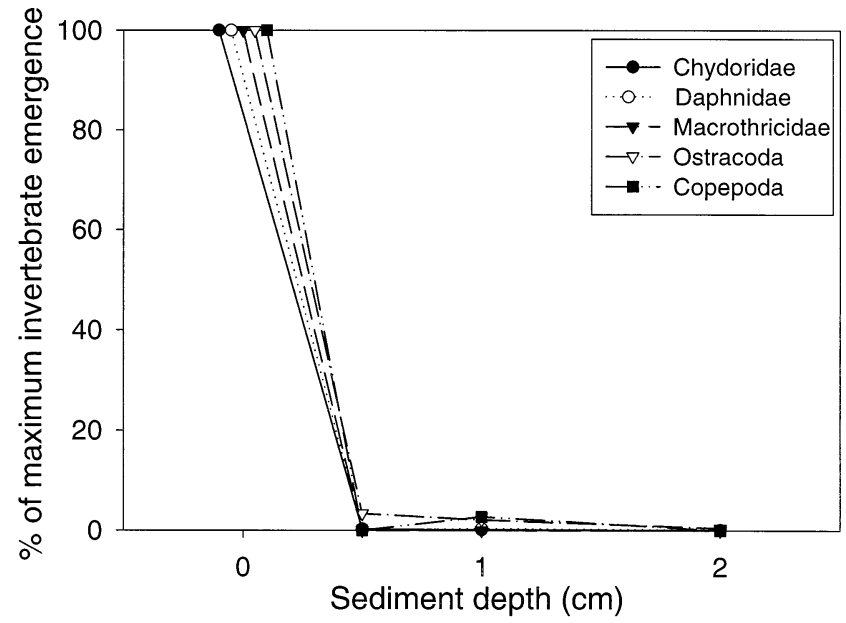

Figure 3. Effect of sediment depth on percent maximum emergence of invertebrate taxa. Percent emergence of invertebrates in the $0.5-, 1-$, and $2-\mathrm{cm}$ treatments is relative to maximum emergence of invertebrates in the $0-\mathrm{cm}$ treatment.

ment treatment $(0.5 \mathrm{~cm})$ nearly eliminated emergence of all aquatic invertebrates from soil egg banks $\left(F_{3,108}\right.$ $=70.0, P<0.001$ ) (Figure 2). A total of 9,838 invertebrates emerged from the 0 -cm sediment depth treatment (i.e., reference), 29 from the $0.5-\mathrm{cm}$ treatment, 21 from the $1-\mathrm{cm}$ treatment, and 5 from the $2-\mathrm{cm}$ treatment. Of the 37 wetland soil samples covered with sediment, $84 \%, 84 \%$, and $92 \%$ failed to hatch invertebrates when covered with $0.5 \mathrm{~cm}, 1 \mathrm{~cm}$, and $2 \mathrm{~cm}$ of sediment, respectively. In contrast, only $14 \%$ of the $0-\mathrm{cm}$ sediment cover treatments failed to hatch invertebrates. Our data indicated that $0.5 \mathrm{~cm}$ of sediment overburden reduced emergence of all invertebrate taxa present in our samples (Table 2; Figure 3).

\section{Effects of Sediment Load on Seedling Emergence}

Covering wetland soils with $0.5,1$, and $2 \mathrm{~cm}$ of sediment reduced $\left(F_{3,105}=257, P<0.001\right)$ emergence of seedlings from soil seed banks (Figure 4). A total of 784 seedlings emerged from the $0-\mathrm{cm}$ treat-

Table 2. Back-transformed mean number of individuals and 95\% confidence intervals (CI) of invertebrate taxa incubated from soil egg banks in four sediment load treatments. Means within rows with a common letter are not significantly different $(P>0.05)$.

\begin{tabular}{|c|c|c|c|c|c|c|c|c|}
\hline \multirow[b]{2}{*}{ Taxa } & \multicolumn{4}{|c|}{ Sediment Depth (cm) } & \multicolumn{3}{|c|}{ ANOVA } & \multirow[b]{2}{*}{$n^{\mathrm{a}}$} \\
\hline & $\begin{array}{c}0 \\
\text { Mean }(95 \% \text { CI })\end{array}$ & $\begin{array}{c}0.5 \\
\text { Mean }(95 \% \text { CI })\end{array}$ & $\begin{array}{c}1 \\
\text { Mean }(95 \% \text { CI })\end{array}$ & $\begin{array}{c}2 \\
\text { Mean }(95 \% \mathrm{CI})\end{array}$ & df & $F$ & $P$ & \\
\hline Chydoridae & 46.2a (27.8-76.4) & $0.2 b(0.0-0.9)$ & $0.1 \mathrm{~b}(0.0-0.8)$ & $0.1 \mathrm{~b}(0.0-0.8)$ & 3,75 & 61.5 & $<0.0001$ & 26 \\
\hline Ostracoda & 4.8a (3.6-6.3) & $0.2 b(0.0-0.5)$ & $0.1 \mathrm{~b}(0.0-0.4)$ & $<0.0 \mathrm{~b}(0.0-0.3)$ & 3,75 & 53.2 & $<0.0001$ & 26 \\
\hline Daphnidae & 10.1a (5.3-18.7) & $0.0 \mathrm{~b}(0.0-0.8)$ & $0.1 b(0.0-1.0)$ & $<0.0 \mathrm{~b}(0.0-0.9)$ & 3,42 & 17.4 & $<0.0001$ & 15 \\
\hline Copepoda & $2.5 \mathrm{a}(0.9-5.7)$ & $0.0 \mathrm{~b}(0.0-0.9)$ & $0.1 \mathrm{~b}(0.0-1.2)$ & $0.0 \mathrm{~b}(0.0-0.9)$ & 3,12 & 5.2 & 0.0159 & 5 \\
\hline Macrothricidae & 75.8a (3.0-1469.9) & $0.0 \mathrm{a}(0.0-18.2)$ & $0.0 \mathrm{a}(0.0-18.2)$ & $0.0 \mathrm{a}(0.0-18.2)$ & 3,3 & 5.5 & 0.0982 & 2 \\
\hline
\end{tabular}

\footnotetext{
a $n=$ the total number of wetlands out of 37 in which the taxa occurred.
} 


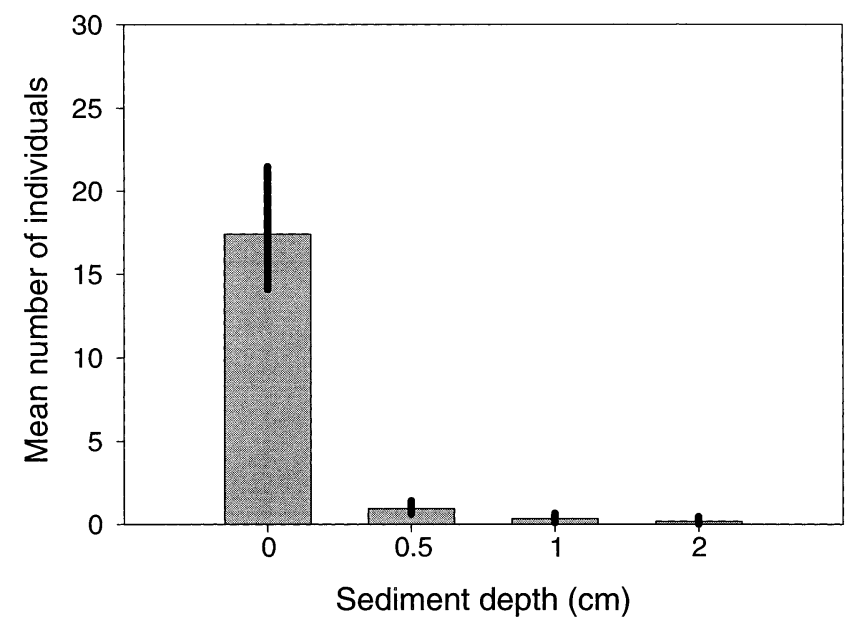

Figure 4. Back-transformed mean abundances and 95\% confidence intervals of seedlings emerging from seed banks in each sediment-burial treatment.

ment, 65 from the $0.5-\mathrm{cm}$ treatment, 19 from the $1-\mathrm{cm}$ treatment, and 11 from the $2-\mathrm{cm}$ treatment. At the species level, $0.5 \mathrm{~cm}$ of sediment reduced emergence in nearly all cases (Table 3 ). Of the 40 plant species that emerged from the $0-\mathrm{cm}$ treatment, 11,7 , and 4 emerged from the $0.5,1$, and 2 -cm treatments, respectively (Table 3 ). Seven taxa that emerged from the 1$\mathrm{cm}$ treatment included: Eleocharis spp., Juncus interior, Juncus dudleyi, Alisma plantago-aquatica, Scirpus acutus/validus, Sagittaria cuneata, and Sparganium eurycarpum. All of these seven taxa showed decreased emergence when covered with $0.5 \mathrm{~cm}$ of sediment (Figure 5). The 2-cm treatment stopped seedling emergence of Sagittaria cuneata and Alisma plantago-aquatica, whereas seedling emergence of Scirpus acutus/validus and Sparganium eurycarpum was not completely eliminated by the $2-\mathrm{cm}$ treatment (Figure 5). Alisma plantago-aquatica, Sagittaria cuneata, Scirpus acutus/validus, and Sparganium eurycarpum showed more resilience to sediment depth than Eleocharis spp., Juncus interior, and Juncus dudleyi (Figure 5).

\section{DISCUSSION}

The lowest sediment load depth of $0.5 \mathrm{~cm}$ essentially halted invertebrate and seedling emergence. Our results corroborated earlier findings of the negative impact of sediment burial on emergence of hydrophytes from soil seed banks (Jurik et al. 1994, Wang et al. 1994). Additionally, our results suggest that invertebrate emergence is more sensitive to burial than is seedling emergence (Figure 6).

Studies have suggested that seeds with the largest mass often are least effected by burial (Jurik et al.
1994, Wang et al. 1994, Dittmar and Neely 1999). We did not determine seed mass during our study, but relative seed lengths (as a proxy of mass) from species descriptions (Larson 1993) indicate that a positive relationship between seed size and resilience to burial. Juncus torreyi and Juncus interior both have smaller seeds $(0.3-0.4 \mathrm{~mm})$ than Eleocharis spp. (1.4-1.7 mm; based on E. macrostachya Britt.), the latter being more resilient to burial (Figure 5). All three of these taxa were less resilient to burial than larger-seeded species (Scirpus acutus/validus $=1.5-2.2 \mathrm{~mm}$, Alisma plantago-aquatica $=2-2.5 \mathrm{~mm}$, Sagittaria cuneata $=2-$ $3 \mathrm{~mm}$, Sparganium eurycarpum $=6-8 \mathrm{~mm})$. Three species showed more tolerance to burial (Sparganium eurycarpum, Scirpus acutus/validus, and Sagittaria cuneata). Jurik et al. (1994) also found Sagittaria spp. emergence to increase with moderate burial $(0.5 \mathrm{~cm})$. In contrast to plant responses that varied by taxa, invertebrate taxa identified in our experiments were all suppressed by burial (Figure 3). Presumably, egg mass does vary among the taxa that emerged during our experiments; however, we did not measure egg mass, and we are aware of no literature to assess this variation. It is possible that, at lower sediment burial depths (i.e., $<0.5 \mathrm{~cm}$ ), invertebrate taxa may vary in their response to sediment burial.

The effects of sediment on environmental cues necessary for the hatching of invertebrate eggs and germination of seeds was not determined during our study. The presence of sediment likely affected some combination of temperature, light, and oxygen concentration requirements that are known cues for hatching of eggs (Wiggins et al. 1980, Dodson and Frey 1991) and germination of seeds (Baskin and Baskin 1998). Analogous to seed requirements for specific environmental conditions to terminate dormancy (e.g., cold stratification; Baskin and Baskin 1998), resting eggs also need to be exposed to diapause termination conditions (e.g., storage duration, temperature, desiccation, aeration; Wiggins et al. 1980, Dodson and Frey 1991, Moreira dos Santos and Persoone 1998). Storage of seed- and invertebrate egg-bank samples and preparation of experimental flats (i.e., manipulation of soil samples) likely provided some of the conditions necessary to terminate dormancy and diapause. However, the extent to which the covering with sediment inhibited cues needed for termination of diapause or dormancy, or cues for hatching and germination of already activated propagules is not known. The presence of sediment also may have created a physical barrier to emergence. Nevertheless, our burial treatment was associated with sharply decreased emergence of plants and invertebrates.

Our lowest sediment burial treatment $(0.5 \mathrm{~cm})$ was within the range of sedimentation rates $(0.4-0.8 \mathrm{~cm}$ 


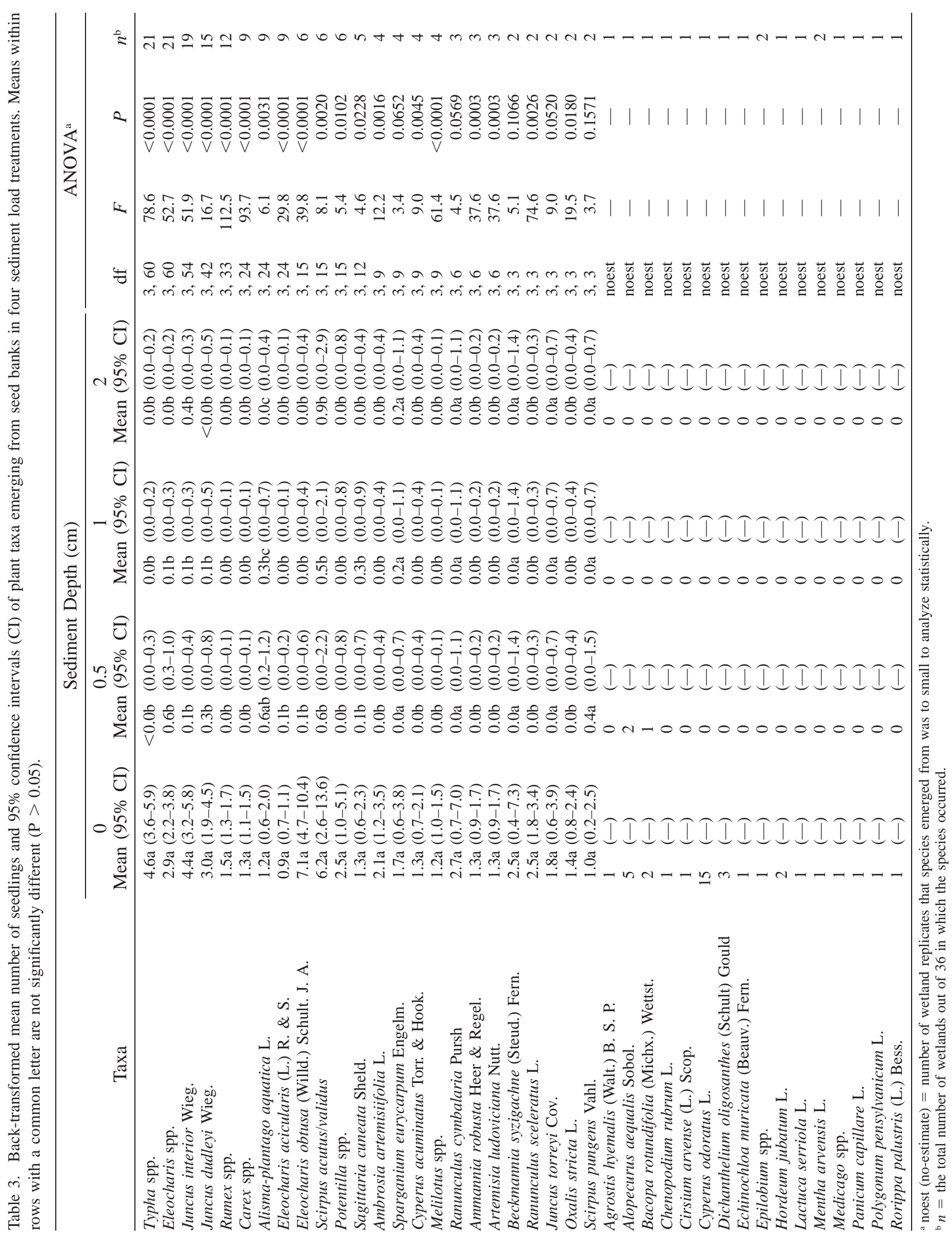




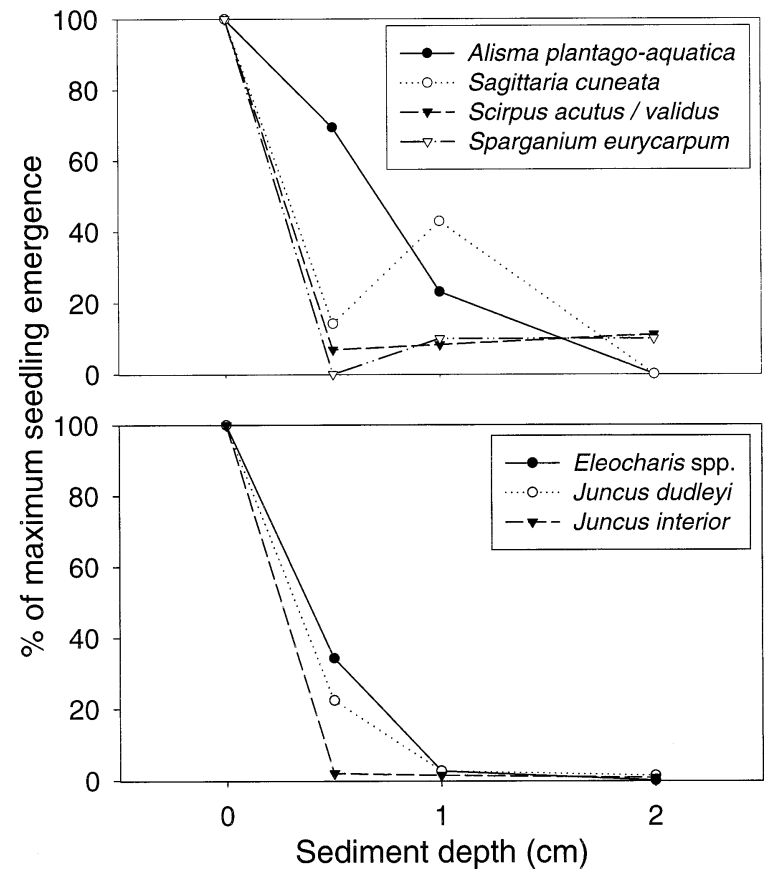

Figure 5. Effect of sediment depth on percent maximum emergence by plant taxa. Percent emergence of seedlings in the $0.5-, 1-$, and $2-\mathrm{cm}$ treatments is relative to maximum emergence of seedlings in the $0-\mathrm{cm}$ treatment.

$\mathrm{yr}^{-1}$ ) reported for wetlands in cultivated catchments (Martin and Hartman 1987, Gleason 2001). However, severe erosion of cropland soils during heavy precipitation events may lead to substantially greater sedimentation rates (Gleason 1996 and 2001). Consequently, we suggest that wetland sedimentation from agricultural activities may limit reestablishment of plants and invertebrates. However, we did not evaluate potential synergistic and indirect effects of accelerated sedimentation on production of plant and invertebrate propagules. For example, many aquatic invertebrates are collector-gatherers or grazers, consuming periphyton associated with detrital food webs and vegetative substrates. Decreases in primary productivity and loss of standing vegetative structure (Krecker 1939, Rosine 1955, Krull 1970, Euliss and Grodhaus 1987) may reduce invertebrate production. Similarly, suspended sediments associated with sediment inputs (Dieter 1991) decrease light penetration, which can decrease phytoplankton biomass and productivity. Increased suspended sediments and concomitant reduction in phytoplankton concentration have been shown to reduce population growth rates of cladocerans (Arruda et al. 1983, McCabe and O'Brien 1983, Kirk and Gilbert 1990). High concentrations of suspended clay that affects the feeding rate of zooplankton and lowers their assimilation efficiency (Robinson 1957, McCabe and O'Brien 1983) may also reduce energy available for reproduction of resting eggs.

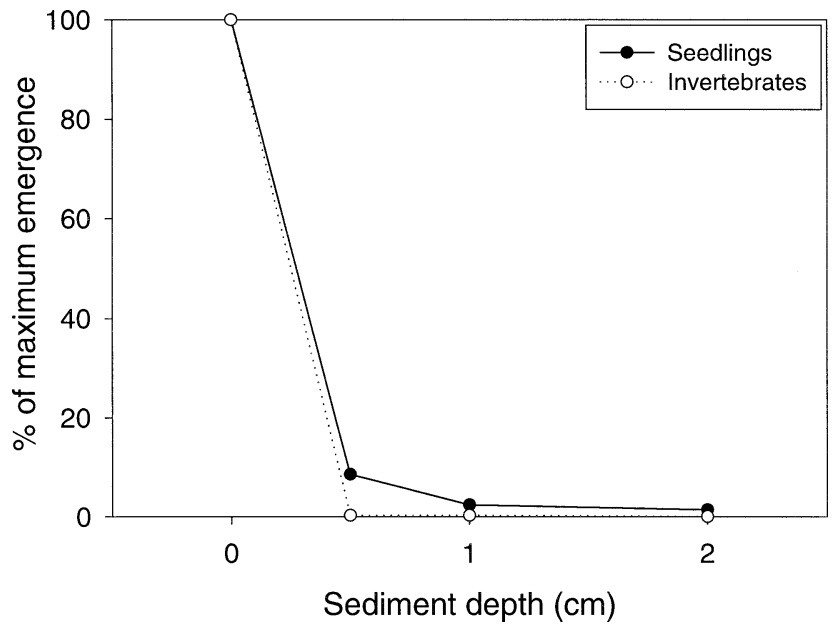

Figure 6. Effect of sediment depth on percent maximum emergence of invertebrates and seedlings. Percent emergence in the $0.5-, 1-$, and $2-\mathrm{cm}$ treatments is relative to maximum emergence in the $0-\mathrm{cm}$ treatment.

During severe drought, most prairie wetlands are completely dry, and many are cultivated. When wetlands reflood, initial colonization of many invertebrate taxa comes from invertebrate egg banks. Cultivation of dry wetlands, in conjunction with sediment inputs, may severely impact recovery of invertebrate populations during wet periods. Further, in wetlands that dry infrequently, increased suspended sediments may decrease survivorship and fecundity of existing invertebrate populations (Arruda et al. 1983, Kirk and Gilbert 1990). Invertebrates and plants are key components for nearly all ecological functions in wetlands. Invertebrates are important in nutrient cycling (Merritt et al. 1984) and in trophic support for many species of wetland-dependent wildlife, such as waterfowl (Swanson 1985). Similarly, a diversity of vegetation provides important nesting structure for birds, as well as invertebrate habitat. Studies are needed to identify minimally acceptable sediment loads $(<0.5 \mathrm{~cm})$ in order to maximize emergence of invertebrates and plants from their propagules. In addition to controlled laboratory experiments, research on the broad spectrum of agricultural land-use practices (e.g., from no-till to conventional agricultural practices) is needed to elucidate relationships between intensity of cultivation and sedimentation on egg-bank and seed-bank maintenance and viability. Knowledge gained from such studies will provide insight into which agricultural practices should be promoted to enhance productivity and sustain wetlands on agricultural lands.

\section{ACKNOWLEDGMENTS}

For their assistance and cooperation, we thank the U.S. Fish and Wildlife Service (Region 3 and 6), U.S. 
Department of Agriculture Natural Resources Conservation Service, Minnesota Department of Natural Resources, South Dakota Department of Game, Fish, and Parks, Iowa Department of Natural Resources, and the many land owners in Montana, North Dakota, South Dakota, Minnesota, and Iowa who granted access to wetlands on private lands. A special thanks goes to the U.S. Department of Agriculture's Agricultural Research Service Northern Plains Insects Laboratory for providing the greenhouse facilities to conduct our experiments. Additionally, we thank Paul Coughlin of the South Dakota Department of Game, Fish, and Parks for participating in a U.S. Department of Interior State partnership proposal to acquire funding for this project. We also thank Brian Check, Chris Locken, and Kyle Kelsey for assistance with field collections and emergence experiments; Wesley Newton and Deb Buhl for their statistical assistance; David Mushet and Bruce Hanson for coordinating many activities related to this project; and Tom Skelbar and Ann Dahl for providing GIS and mapping assistance. We also thank Jane Austin, Susan Galatowitsch, Mark Hanson, Henry Murkin, Roger Pederson, and Loren Smith for providing editorial review on earlier drafts of this manuscript.

\section{LITERATURE CITED}

Adomaitis, V. A., H. A. Kantrud, and J. A. Shoesmith. 1967. Some chemical characteristics of aeolian deposits of snow-soil on prairie wetlands. Proceedings of the North Dakota Academy of Science 21:65-69.

Arruda, J. A., G. R. Marzolf, and R. T. Faulk. 1983. The role of suspended sediments in the nutrition of zooplankton in turbid reservoirs. Ecology 64:1225-1235.

Baskin, C. C. and J. M. Baskin. 1998. Seeds: Ecology, Biogeography, and Evolution of Dormancy and Germination. Academic Press, San Diego, CA, USA.

Bluemle, J. P. 1977. The face of North Dakota: the geologic story. North Dakota Geological Survey, Bismarck, ND, USA. Educational Series 11.

Dieter, C. E. 1991. Water turbidity in tilled and untilled prairie wetlands. Journal of Freshwater Ecology 6:185-189.

Dittmar, L. A. and R. K. Neely. 1999. Wetland seed bank response to sedimentation varying in loading and texture. Wetlands 19:341351.

Dodson, S. I. and D. G. Frey. 1991. Cladocera and other branchiopoda. p. 723-726. In J. H. Thorp and A. P. Covich (eds.) Ecology and Classification of North American Freshwater Invertebrates. Academic Press, Inc., San Diego, CA, USA.

Euliss, N. H., Jr. and G. Grodhaus. 1987. Management of midges and other invertebrates for waterfowl wintering in California. California Fish and Game 73:238-243.

Euliss, N. H., Jr. and D. M. Mushet. 1999. Influence of agriculture on aquatic invertebrate communities of temporary wetlands in the prairie pothole region of North Dakota, USA. Wetlands 19:578583.

Euliss, N. H., Jr., D. A. Wrubleski, and D. M. Mushet. 1999. Invertebrates in wetlands of the prairie pothole region: species composition, ecology, and management. p. 471-513. In D. P. Batzer, R. B. Rader, and S. A. Wissinger (eds.) Invertebrates in Freshwater Wetlands of North America: Ecology and Management. John Wiley \& Sons, New York, NY, USA.

Galatowitsch, S. M. and A. G. van der Valk. 1994. Restoring Prairie
Wetlands: an Ecological Approach. Iowa State University Press, Ames, IA, USA.

Galatowitsch, S. M. and A. G. van der Valk. 1996. The vegetation of restored and natural prairie wetlands. Ecological Applications 6:102-112.

Galinato, M. I. and A. G. van der Valk. 1986. Seed germination traits of annuals and emergents recruited during drawdowns in the Delta Marsh, Manitoba, Canada. Aquatic Botany 26:89-102.

Gleason, R. A. 1996. Influence of agricultural practices on sedimentation rates, aquatic invertebrates, and bird-use in prairie wetlands. M.S. Thesis. Humboldt State University, Arcata, CA, USA.

Gleason, R. A. 2001. Invertebrate egg and plant seed banks in natural, restored, and drained wetlands in the prairie pothole region (USA) and potential effects of sedimentation on recolonization of hydrophytes and aquatic invertebrates. Ph.D. Dissertation. South Dakota State University, Brookings, SD, USA.

Gleason, R. A. and N. H. Euliss, Jr. 1998. Sedimentation of prairie wetlands. Great Plains Research 8:97-112.

Great Plains Flora Association. 1986. Flora of the Great Plains. University Press of Kansas, Lawrence, KS, USA.

Hartleb, C. F., J. D. Madsen, and C. W. Boylen. 1993. Environmental factors affecting seed germination in Myriophyllum spicatum L. Aquatic Botany 45:15-25.

Hathaway, S. A., D. P. Sheehan, and M. A. Simovich. 1996. Vulnerability of branchiopod cysts to crushing. Journal of Crustacean Biology 6:448-452.

Jurik, T. W., S.-C. Wang, and A. G. van der Valk. 1994. Effects of sediment load on seedling emergence from wetland seed banks. Wetlands 14:159-165.

Kantrud, H. A. 1993. Duck nest success on conservation reserve program land in the prairie pothole region. Journal of Soil and Water Conservation 48:238-242.

Kasahara, S., T. Onbe, and M. Kamigaki. 1975. Calanoid copepod eggs in sea bottom muds: III. effects of temperature, salinity, and other factors on the hatching of resting eggs of Tortanus forcipatus. Marine Biology 31:31-35.

Kirk, K. L. and J. J. Gilbert. 1990. Suspended clay and population dynamics of planktonic rotifers and cladocerans. Ecology 71: 1741-1755.

Krecker, F. H. 1939. A comparative study of the animal population of certain submerged aquatic plants. Ecology 20:553-562.

Krull, J. N. 1970. Aquatic plant-macroinvertebrate associations and waterfowl. Journal of Wildlife Management 34:707-718.

Larson, G. E. 1993. Aquatic and wetland vascular plants of the northern Great Plains. U.S. Department of Agriculture, Forest Service, Rocky Mountain Forest and Range Experiment Station, Fort Collins, CO, USA. General Technical Report RM-238

Luo, H. R., L. M. Smith, B. L. Allen, and D. A. Haukos. 1997. Effects of sedimentation on playa wetland volume. Ecological Applications 7:247-252.

Luo, H. R., L. M. Smith, D. A. Haukos, and B. L. Allen. 1999. Sources of recently deposited sediments in playa wetlands. Wetlands 19:176-181.

Martin, D. B., and W. A. Hartman. 1987. The effect of cultivation on sediment composition and deposition in prairie pothole wetlands. Water, Air, and Soil Pollution 34:45-53.

McCabe, G. D. and W. J. O'Brien. 1983. The effects of suspended silt on feeding and reproduction of Daphnia pulex. American Midland Naturalist 110:324-337.

Merritt, R. W., K. W. Cummins, and T. M. Burton. 1984. The role of aquatic insects in the processing and cycling of nutrients. p. 134-163. In V. H. Resh and D. M. Rosenburg (eds.) The Ecology of Aquatic Insects. Praeger, New York, NY, USA.

Milliken, G. A. and D. E. Johnson. 1984. Analysis of Messy Data, Volume 1: Designed Experiments. Van Nostrand Reinhold Company, New York, NY, USA.

Moreira dos Santos, M. M. and G. Persoone. 1998. Hatching of Daphnia magna resting eggs: the effect of storage duration and storage temperature. Advances in Limnology 53:253-262.

Pennak, R. W. 1989. Fresh-water Invertebrates of the United States. Third edition. John Wiley and Sons Inc., New York, NY, USA.

Robinson, M. 1957. The effects of suspended materials on the re- 
productive rate of Daphnia magna. Publication of the Institute of Marine Science University of Texas 4:265-277.

Rosine, W. N. 1955. The distribution of invertebrates on submerged aquatic plant surfaces in Muskee Lake, Colorado. Ecology 36: 308-314.

SAS Institute, Inc. 1997. SAS/STAT software: changes and enhancements through release 6.12. SAS Institute, Inc., Cary, NC, USA.

Swanson, G. A. 1985. Invertebrates consumed by dabbling ducks (Anatinae) on the breeding grounds. Journal of Minnesota Academy of Sciences 50:37-40.

Steel, R. G. D. and J. H. Torrie. 1980. Principles and Procedures of Statistics: a Biometrical Approach. McGraw Hill, New York, NY, USA.

Stewart, R. E. and H. A. Kantrud. 1971. Classification of natural ponds and lakes in the glaciated prairie region. U.S. Fish and Wildlife Service Resource Publication 92.

Uye, S., S. Kasahara, and T. Onbe. 1979. Calanoid copepod eggs in sea bottom muds: IV. effects of some environmental factors on the hatching of resting eggs. Marine Biology 51:151-156.

van der Valk, A. G. 1981. Succession in wetlands: a Gleasonian approach. Ecology 62:688-696.

van der Valk, A. G. and C. B. Davis. 1978. The role of seed banks in the vegetation dynamics of prairie glacial marshes. Ecology 59: 322-335.

Wang, S.-C., T. W. Jurik, and A. G. van der Valk. 1994. Effects of sediment load on various stages in the death of cattail (Typha $\times$ glauca). Wetlands 14:166-173.

Wienhold, C. E. and A. G. van der Valk. 1989. The impact of duration of drainage on the seed banks of northern prairie wetlands. Canadian Journal of Botany 67:1878-1884.

Wiggins, G. B., R. J. Mackay, and I. M. Smith. 1980. Evolutionary and ecological strategies of animals in annual temporary pools. Archiv für Hydrobiologie Supplement 58:97-206.

Manuscript received 1 March 2002; revisions received 16 September 2002; accepted 18 November 2002. 